\title{
Investigation on competitors and predators of herbivorous aquatic Lepidoptera (Acentria ephemerella) on submersed macrophytes in a large prealpine lake
}

\author{
E. M. Gross and R. Kornijów
}

\section{Introduction}

Submersed macrophytes offer a large colonization area for many macroinvertebrates. Numerous studies investigated the interaction between plant species, growth and leaf form and the abundance and species composition of invertebrates (e.g. SosZKA 1975 , KORNIJOW \& KaIRESAlO 1992). Grazers and detrivores assist the plants by removing epiphyton and allowing more light to reach the photosynthetic tissue. Only recently has the paradigm that aquatic angiosperms are not subjected to a high degree of herbivory been challenged (LODGE 1991, NEWMAN 1991, KorniJów 1996, LODGE et al. 1998). A detailed study of the literature reveals that aquatic insects were frequently observed feeding on submersed macrophytes. For example, Acentria ephemerella, a true shredder-herbivore, was found associated with pondweeds and other macrophytes in several studies (Berg 1942, Müller-Liebenau 1956, SoszKa 1975). Acentria seems to prefer large lakes to small ponds as habitat (JoHnson et al. 1998). Data on its abundance in different lakes range from a few dozen to many hundred species per square meter (SOSZKA 1975, Hedal \& Schmidt 1992, Bänziger 2000, JoHnson et al. 2001, Gross et al. in prep.).

In Lake Constance, Acentria is the major invertebrate herbivore and regularly develops exponentially increasing densities during the vegetation period (Gross et al. in prep.). However, information is still lacking on the relationship between the abundance of this herbivore and the resulting damage to different macrophyte species (JoHnson et al. 2001, Gross et al. 2001). Very little is also known on the interactions with other invertebrates, especially competitors and predators. Therefore, the aim of this study was to learn the guild structure of the epiphytic macroinvertebrate communities inhabiting various elodeids in Lake Constance with analyses of potential competitors and predators of Acentria.

\section{Methods}

Lake Constance is the second largest $\left(571 \mathrm{~km}^{2}\right)$ prealpine lake in Europe. The lake has three major basins, the Überlinger See, the Upper Lake and the Lower Lake. The Lower Lake $\left(71 \mathrm{~km}^{2}\right)$ is shallow (max. depth $46 \mathrm{~m}, 28 \%$ littoral area defined as area above $10 \mathrm{~m}$ water depth). This part supports luxurious submersed macrophyte growth.

In order to determine the seasonal and spatial dynamics of Acentria ephemerella, macrophyte stands at different sites in the Überlinger See and Lower Lake Constance were sampled regularly during the vegetation period from 1998 to 2000 (Gross et al. in prep.). The samples for analyses of the animal guild structure were collected during August-September 2000 from Potamogeton perfoliatus, P. pectinatus and Myriophyllum spicatum at the western tip of the island, from two different locations. They were situated about $300 \mathrm{~m}$ from each other, at a depth of between 2 and $2.5 \mathrm{~m}$, depending on the water gauge level of the lake.

In addition to the $0.1-\mathrm{m}^{2}$ samples taken for the evaluation of Acentria abundance, one or two shoots of each macrophyte were carefully selected at the sediment interface and pushed gently in an upward moving sweep net (mesh width $240 \mu \mathrm{m}$ ) to avoid loss of highly mobile macroinvertebrates. Three replicate samples from each macrophyte were collected at each sampling location .

All samples were taken snorkelling. Samples were concentrated in mesh beakers and transferred with water into 1-L sealable (Ziploc TM) bags. After sorting, the macroinvertebrates were preserved in $70 \%$ ethanol. The absolute number of Dreissena polymorpha is probably underestimated because not all specimens were preserved. The dry weight of the macrophyte shoots was determined after drying at $100{ }^{\circ} \mathrm{C}$ for $48 \mathrm{~h}$. The density of macroinvertebrates was calculated per $100 \mathrm{~g}$ of plant dry weight. 


\section{Results}

Density of Acentria

In 1998, Acentria developed densities, in dense stands of both Potamogeton perfoliatus and Myriophyllum spicatum, of $10-8000$ ind. $/ \mathrm{m}^{2}$ lake area. That year exhibited extremely low summer water levels allowing lush macrophyte growth. In late spring and early summer of 1999, Lake Constance exhibited a very high water level ( $2 \mathrm{~m}$ higher than normal for this time of the year) due to massive precipitation in the northern catchment area. This severely interfered with normal submersed macrophyte growth, which usually starts in May. Consequently, maximum densities of Acentria found in 1999 reached only about 100 ind. $/ \mathrm{m}^{2}$ from August until the end of October. During 2000, water levels were close to the long-term annual mean, and pondweeds developed normally. Only $M$. spicatum failed to build up the dense stands observed in the previous years and reached only 150-175 g DW per $\mathrm{m}^{2}$ in September 2000 compared with ca. $350 \mathrm{~g}$ DW per $\mathrm{m}^{2}$ in 1998. Acentria density dropped from 2420 ind./100 g DW at the end of September 1998 to 243 ind./100 g DW at the same time in 2000. The mean summer percentage of Acentria in the total density of epiphytic fauna on Potamogeton perfoliatus, P. pectinatus and Myriophyllum spicatum in 2000 differed considerably and amounted to $11 \%, 31 \%$ and $1.3 \%$, respectively.

Guild structure of the animal epiphytic communities

The analysis of the plant-associated macrofauna occurring on the vegetation during late summer 2000 exhibited a diverse community, composed of 27 taxa, of which 25 were found on Potamogeton perfoliatus, 6 on $P$. pectinatus and 12 on Myriophyllum spicatum. The total mean faunal densities amounted to 2819, 397 and 2137 ind./100 g DW, respectively.

The communities can be pooled into three groups: vascular plant feeders (two species), omnivores (18 taxa) and predators (seven taxa). The most abundant were omnivores (Table 1) with predominating chironomid larvae Endoch- ironomus albipennis $(81 \%, 24 \%$ and $71 \%$ by numbers, respectively). The second most numerous group was the herbivores, represented by only two species, among which Acentria ephemerella predominated (98\%, 100\% and $87 \%$ ) over Macroplea appendiculata (Chrysomelidae). Predators occurred in relatively low numbers and only on $P$. perfoliatus and $M$. spicatum.

\section{Discussion}

Acentria ephemerella is an important invertebrate herbivore in Lower Lake Constance, causing extensive damage to aquatic vegetation. Since its abundance increases almost exponentially during the vegetation period, other members of the macroinvertebrate community are potential competitors or predators of this species. In previous studies, the only predators found associated with Acentria were planaria (Dugesia sp.) and dytiscid larvae (BUCKINGHAM \& Ross 1981). In studies of lakes in the US, Acentria was frequently associated with the herbivorous cucurlionid Euhrychiopsis lecontei $(26$ out of 34 lakes shared both herbivores (Johnson et al. 1998).

Many species classified in this study as omnivores consume plant tissue, also, although in small quantities. They can interact with Acentria in various ways. For example, the predominating photophilous larvae Endochironomus albipennis occur mainly in the upper stem sections of submersed macrophytes (ZHGarieva 1982), the same habitat used by Acentria (Gross et al. 2001). They overwinter in the bottom sediments but live on various macrophytes during the vegetation period, with maximum abundance during midsummer (KoRNijów 1992). The larvae may benefit from herbivory by Acentria due to damage of the leaves causing leaching of cell sap and the production of faecal pellets still rich in nutrients, which can lead to the subsequent higher production of bacterial and algal epiphytes. On the other hand, Acentria benefits from epiphyte grazers since they remove dense layers of algae, especially filamentous species, which can severely interfere with the feeding on macrophyte tissue. 
Table 1. List of invertebrates (per $100 \mathrm{~g} \mathrm{DW}$ ) associated with the herbivorous Acentria ephemerella (Lepidoptera: Pyralidae) on Potamogeton perfoliatus, P. pectinatus and Myriophyllum spicatum in late summer in Lower Lake Constance. ${ }^{*}$ Indicates potential predators.

\begin{tabular}{|c|c|c|c|}
\hline Taxa & P. perfoliatus & P. pectinatus & M. spicatum \\
\hline \multicolumn{4}{|l|}{ Hirudinea } \\
\hline Erpobdella sp.* & 17 & & \\
\hline Glossiphonia heteroclita* & 1 & & \\
\hline Helobdella stagnalis* & 17 & & \\
\hline \multicolumn{4}{|l|}{ Oligochaeta } \\
\hline Stylaria lacustris & 9 & & 21 \\
\hline Naididae n. det & 84 & 71 & \\
\hline \multicolumn{4}{|l|}{ Gastropoda } \\
\hline Bithynia tentaculata & 106 & & \\
\hline Gyraulus albus & 3 & & \\
\hline \multicolumn{4}{|l|}{ Planorbis planorbis } \\
\hline \multicolumn{4}{|l|}{ Bivalvia } \\
\hline Dreissena polymorpha & 140 & 95 & 306 \\
\hline Sphaeridae & 2 & & \\
\hline \multicolumn{4}{|l|}{ Crustacea } \\
\hline Gammarus sp.* & 10 & & \\
\hline Hydracarina* & & & 63 \\
\hline \multicolumn{4}{|l|}{ Ephemeroptera } \\
\hline Caenis sp. & 7 & & \\
\hline \multicolumn{4}{|l|}{ Zygoptera } \\
\hline \multicolumn{4}{|l|}{ Trichoptera } \\
\hline Athripsodes atterimus $l$. & 53 & 44 & 37 \\
\hline Athripsodes atterimus $p$. & 57 & 9 & 332 \\
\hline Trichoptera non. det. & 6 & & \\
\hline \multicolumn{4}{|l|}{ Lepidoptera } \\
\hline Acentria ephemerella l. & 283 & 123 & 12 \\
\hline Acentria ephemerella $p$. & 34 & & 16 \\
\hline \multicolumn{4}{|l|}{ Chrysomelidae } \\
\hline Macroplea appendiculata & 5 & & 11 \\
\hline \multicolumn{4}{|l|}{ Chironomidae } \\
\hline Ablabesmyia sp.* & & & 7 \\
\hline Corynoneura lobata & 5 & & \\
\hline Cricotopus sp. (gr. silvestris) & 25 & & 7 \\
\hline Endochironomus albipennis & 1801 & 43 & 1163 \\
\hline Limnochironomus sp. & 39 & 11 & 14 \\
\hline Orthocladiinae non. det. & 5 & & \\
\hline Paratanytarsus sp. (gr. lauterborni) & 6 & & 71 \\
\hline Parachironomus varus & 10 & & 42 \\
\hline Psectrocladius gr. sordidellus & 4 & & \\
\hline Chironomidae pupa & 185 & & 35 \\
\hline Fauna total per $100 \mathrm{~g} \mathrm{DW}$ & 2819 & 397 & 2137 \\
\hline
\end{tabular}


Colonization of macrophytes by Dreissena should not interfere with the active feeding of Acentria. However, dense Dreissena coverage at lower stem sections could interfere with stem boring of Acentria for winter diapause. The same Dreissena cover may prevent predation by invertebrate omnivores or predators on stems containing Acentria. Anyhow, predatory macroinvertebrates present in association with Acentria larvae, due to their low size and densities, seem unlikely to threaten larger instar larvae. Only egg clutches and young instar larvae might be susceptible to predation, e.g. by leeches and predatory chironomid larvae of the midge larvae. Acentria larvae are very cryptic: first and second instars mine in leaves. Older instars build retreats with leaf material, either by cutting a disk of leaf material and attaching it 'sandwich-like' to their back or by connecting leaflets of milfoil in a tube-like manner. Mortality of Acentria was assumed to be low during the active feeding period (May to early September), which was reflected in the almost exponential increase of density. Mortality was obviously high during the winter months when larvae stayed in remnants of lower shoot sections.

The only other true macrophyte herbivore, Macroplea appendiculata, usually occurs in much lower densities than Acentria on P. perfoliatus (5 Macroplea compared to 283 Acentria larvae and 34 pupae per 100 g DW). Approximately the same density of both species was observed on M. spicatum (11 Macroplea versus 16 Acentria larvae and 12 pupae per $100 \mathrm{~g}$ DW). Larvae of Macroplea usually feed on midstem sections or move to the root area in the late fall. Not much is known about the life history and feeding preferences of this species (Grillas 1988) It has only be found on P. perfoliatus (this study), P. pectinatus and M. spicatum (Grillas (1988) and this study).

\section{Acknowledgement}

We gratefully acknowledge the dedicated work of Claudia Choi, Claudia Feldbaum and numerous research students in processing macrophyte samples to evaluate Acentria abundance during 1998-2000. This work was supported by a grant of the German
Science Foundation (DFG) to EMG (SFB 454, TP A2) and two travel grants to RK (SFB $454 \mathrm{TP}$ Z).

\section{References}

BÄNZIGER, R., 2000: Spatio-temporal distribution of size classes and larval instars of aquatic insects (Ephemeroptera, Trichoptera and Lepidoptera) in a Potamogeton pectinatus L. bed (Lake Geneva, Switzerland). - Rev. Suisse Zool. 107: 139-151.

Batra, S. W. T., 1977: Bionomics of the aquatic moth Acentropus niveus (Oliver), a potential biological control agent for Eurasian watermilfoil and Hydrilla. - NY Entomol. Soc. 85: 143-152.

BerG, K., 1942: Contributions to the biology of the aquatic moth Acentropus niveus (Oliv.). - Vidensk. Medd. Dansk Naturh. Foren. 105: 59-139.

Buckingham, G. R. \& Ross, B. M., 1981: Notes on the biology and host specificity of Acentria nivea (=Acentropus niveus). - J. Aquat. Plant Manage. 19: 32-36.

Grillas, P., 1988: Haemonia appendiculata Panzer (Chrysomolidae, Donaciinae) and its impact on Potamogeton pectinatus L. and Myriophyllum spicatum L. beds in the Camarque (France). - Aquat. Bot. 31: 347-359.

Gross, E. M., Johnson, R. L. \& Hairston, N. G., JR., 2001: Experimental evidence for changes in submersed macrophyte species composition caused by the herbivore Acentria ephemerella (Lepidoptera). - Oecologia in press.

Hedal, S. \& Schmidt, S. C., 1992: On the occurrence of Acentria ephemerella Den. and Schiff. - Entomal. Medd. 60: 17-20.

Johnson, R. L., Gross, E. M. \& Hairston, N. G., JR., 1998: Decline of the invasive submersed macrophyte Myriophyllum spicatum (Haloragaceae) associated with herbivory by larvae of Acentria ephemerella (Lepidoptera). - Aquat. Ecol. 31: 273-282.

Johnson, R. L., van Dusen, P. J., Toner, J. A. \& Hairston, N. G., JR., 2001: Eurasian Watermilfoil biomass associated with insect herbivores in New York. - J. Aquat. Plant Manage. in press.

Kornijów, R., 1992: Seasonal migration by larvae of an epiphytic chironomid. - Freshwater Biol. 27: 85-89.

Kornijów, R., 1996: Cumulative consumption of the lake macrophyte Elodea by abundant generalist invertebrate herbivores. - Hydrobiologia 319: 185-190.

Kornijów, R. \& Kairesalo, T., 1992: Elodea canadensis sustains rich environment for macroinvertebrates. - Verh. Internat. Verein. Limnol. 25: 4098-4111.

Kornijów, R. \& Kairesalo, T., 1994: The response of epiphytic fauna inhabiting two macrophytes of contrasting architecture to experimental fish exclusion in an oligotrophic lake, In: Sutcliffe, D. W. (ed.): Water Quality and Stress Indicators in Marine and Freshwater Systems: Linking Levels of Organisation (Individuals, Populations, Communities). 176-177. - Freshwater Biological Association, Ambleside, UK.

LODGE, D. M., 1991: Herbivory on freshwater macrophytes. 
-Aquat. Bot. 41: 195-224.

Lodge, D. M., Cronin, G., van Donk, E. \& Froelich, A. J., 1998: Impact of herbivory on plant standing crop: comparison among biomes, between vascular and nonvascular plants, and among freshwater herbivore taxa, In: JEPPESEN E., et al. (eds.): The Structuring Role of Submerged Macrophytes in Lakes. 149-174. - Springer, Heidelberg. Series Ecological Studies, Volume 131.

Müller-Liebenau, I., 1956: Die Besiedlung der PotamogetonZone ostholsteinischer Seen. - Arch. Hydrobiol. 52: 470-606.

Newman, R. M., 1991: Herbivory and detritivory on freshwater macrophytes by invertebrates: a review. $-J . N$. Am Benthol. Soc. 10: 89-114.

SoszKA, G. J., 1975: The invertebrates on submerged macro- phytes in three Masurian lakes. - Ekol. Polska 23: 371-391

ZHGaRieva, H. H., 1982: O vertikalnoj strukturie nasielenia zaroslej rdesta raznolistnogo [in Russian]. - Tr. Inst. Biol. Bnutr. Bod AN CCCP 45: 49-56.

Authors' addresses:

E. M. Gross, Limnological Institute, University of Konstanz, 78457 Konstanz, Germany.

E-mail: Elisabeth.Gross@uni-konstanz.de

R. Kornijów, Department of Hydrobiology and Ichthyobiology, University of Agriculture, Akademicka 13, 20-950 Lublin, Poland.

E-mail: rkorn@ursus.ar.lublin.pl 